\title{
Thermomechanical evaluation of sustainable foamed concrete incorporating palm oil fuel ash and eggshell powder
}

\author{
Ashfaque Ahmed Jhatial*, Wan Inn Goh**, Noridah Mohamad**, Kim Hung Mo*** and Atta Mehroz**** \\ *Department of Civil Engineering, Mehran University of Engineering and Technology, Shaheed Zulfiqar Ali Bhutto Campus, Khairpur Mirs', \\ Sindh, Pakistan \\ **Jamilus Research Centre, Faculty of Civil Engineering and Built Environment, Universiti Tun Hussein Onn Malaysia, Parit Raja, 86400 Batu \\ Pahat, Johor, Malaysia \\ ***Department of Civil Engineering, Faculty of Engineering, University of Malaya, 50603 Kuala Lumpur, Malaysia \\ ****Department of Civil Engineering Technology, Government College University, Faisalabad, Punjab, Pakistan \\ *Corresponding Author: ashfaqueahmed@muetkhp.edu.pk
}

Submitted: 01/06/2019

Revised: $\quad 11 / 11 / 2020$

Accepted: 14/12/2020

\begin{abstract}
Increased usage of concrete contributes to urban thermal discomfort due to the Urban Heat Island effect. At the same time, the corresponding increased consumption of cement also causes a significant rise in carbon dioxide $\left(\mathrm{CO}_{2}\right)$ gas emissions. This experimental work aims at evaluating the thermal and mechanical performance of $1800 \mathrm{~kg} / \mathrm{m}^{3} \mathrm{dry}$ density green sustainable foamed concrete (GFC) incorporating agroindustrial waste such as Palm Oil Fuel Ash (POFA) and Eggshell Powder (ESP) as supplementary cementitious materials (SCMs). The POFA content varied from 15 to $35 \%$, with increments of 5\%, while being supplemented with 5\% ESP. To evaluate the performance of the developed GFC, the flowability, mechanical strengths (compressive and splitting tensile strengths), and thermal performances (thermal conductivity and surface temperature) were investigated. Incorporation of $15-25 \%$ of POFA supplemented with 5\% ESP as partial cement replacement materials resulted in enhanced mechanical strengths. Although usage of POFA can reduce the thermal conductivity, the POFA content must be limited to $15-25 \%$ to prevent excessive heat absorption by the exterior surface of the concrete. Overall, the optimum use of $15 \%$ POFA in a combination of $5 \%$ ESP is desirable to produce an eco-friendly sustainable foamed concrete.
\end{abstract}

Keywords: Foamed concrete; Palm oil fuel ash; Eggshell powder; Solid waste management; Thermal properties; Supplementary cementitious materials (SCMs).

\section{INTRODUCTION}

Ease of moulding, availability, practicality and durability aspects have made concrete the most preferred building material in the construction industry. It has been reported that approximately 3 billion metric tons of cement, which is the essential ingredient of concrete, is produced annually worldwide (Jhatial et al., 2020a), contributing up to 7\% of the global carbon dioxide $\left(\mathrm{CO}_{2}\right)$ gas emissions (Zhang et al., 2014; Benhelal et al., 2013). The ever-growing production of cement and subsequent generation of $\mathrm{CO}_{2}$ gas emissions has raised global awareness and prompted researchers to develop alternative and more sustainable concrete. By either utilizing waste materials for environmental conservation or by improving the energy efficiency of the concrete, sustainability could be achieved in the construction industry, as both of which could contribute to the $\mathrm{CO}_{2}$ reductions (Assi et al., 2018). 
Concrete, despite being the preferred construction and building material, tends to absorb heat due to its relatively high thermal conductivity, which causes interior thermal discomfort for the occupants. This causes urban infrastructures to heat up compared to the adjacent rural areas (Jhatial et al., 2017), giving rise to the Urban Heat Island (UHI) effect. It has been reported that cities gain $2{ }^{\circ} \mathrm{C}$, while highly densely populated areas are up to $7{ }^{0} \mathrm{C}$ higher than the surrounding rural areas, whereas they are warmer than the adjacent rural areas (Özyavuz et al., 2015).

Though the utilization of concrete in building and construction projects is inevitable due to its popularity, a modification could be done on concrete to reduce the thermal conductivity, as well as incorporating sustainable materials to address the growing concerns of the global rise in temperature caused by $\mathrm{CO}_{2}$ gas emissions and UHI phenomenon. One of the ideal ways is through the introduction of a sustainable foamed concrete, which incorporates locally available waste materials. A type of lightweight concrete, foamed concrete, is produced by incorporating foaming agent that introduces air voids in the matrix, which allow the foamed concrete to slow down the transfer of heat through a medium, thus providing thermal insulation (Zahari et al., 2009). Thermal conductivity is reduced with a decrease in the density of foamed concrete. The utilization of foamed concrete in urban construction can help reduce the UHI effect and simultaneously decrease the self-weight stress on the structures.

The sustainability of foamed concrete could be further enhanced by recycling waste materials. The proper recycling/ reuse of waste materials, particularly, as supplementary cementitious materials (SCMs) to partially substitute cement, could significantly bring down the $\mathrm{CO}_{2}$ emissions released during the production of cement. The increasing generation of solid wastes has caused a severe challenge to manage these wastes. With growing environmental awareness, scarcity of land, and the ever-increasing cost of waste disposal, utilization of waste materials has garnered increased attention.

The palm oil mill wastes contribute a significantly high proportion of agroindustrial wastes produced annually in Malaysia (Embrandiri et al., 2012); one of the palm oil mill wastes is Palm Oil Fuel Ash (POFA). With the continuous increase in palm oil production, the amount of POFA generated increases adversely, creating a large environmental load (Abdullah et al., 2006). Therefore, researchers have worked on minimizing this load by using POFA as SCM, which also contributes to reducing cement consumption in concrete. Concrete is beneficial in many ways with the incorporation of POFA such as enhancing its resistance to chloride attack, drying shrinkage, improved sulphate resistance, and reduction in the effect of acidic environment on concrete (Tangchirapat et al., 2010; Chindaprasirt et al., 2008; Jaturapitakkul et al., 2007; Tangchirapat et al., 2007; Tay, 1990). An excessive amount of POFA used in replacing cement was reported to result in strength reduction of concrete due to decreased portlandite concentration (Tonnayopas et al., 2016). Researchers have pointed out that POFA, along with secondary calcium-rich waste material, could develop extra calcium silicate hydrate $(\mathrm{C}-\mathrm{S}-\mathrm{H})$ geld due to the continuous supply of $\mathrm{Ca}[\mathrm{OH}]_{2}$ for consumption during pozzolanic activity, which results in improved strength and durability of concrete (Hamad et al., 2018).

Eggshell is another waste available in abundance in Malaysia and is rich in calcium oxide $(\mathrm{CaO})$. Eggshells are considered to be of no practical value; therefore, without any treatment, they are disposed of in the landfills causing significant environmental pollution (Jhatial et al., 2019a; Raji and Samuel, 2015). Interestingly, eggshells powder (ESP) has been used as SCMs, and it was found that replacement of 5\% to 7.5\% of cement is possible (Wei et al., 2020; Jhatial et al., 2019b; Ujin et al., 2017; Dhanalakshmi et al., 2015; Gowsika et al., 2014; Yerramala, 2014). ESP is a potential additional material to supplement POFA as SCMs for enhanced properties of foamed concrete, while simultaneously realizing the concept of sustainable materials with lower cement content and $\mathrm{CO}_{2}$ emission (Jhatial et al., 2018).

This experimental study focused upon the development of a green sustainable foamed concrete (GFC), which incorporates locally available wastes such as POFA and ESP. A dry density of $1800 \mathrm{~kg} / \mathrm{m}^{3}$ was targeted for GFC. The POFA content varied by replacing cement replacement from 15 to $35 \%$, which increments $5 \%$, while being supplemented with 5\% ESP. To investigate the performance of the developed sustainable foamed concrete, the flowability, mechanical strengths (compressive and splitting tensile strengths), and thermal performances (thermal conductivity and surface temperature) were assessed. 


\section{EXPERIMENTAL WORK}

\section{MATERIALS}

OPC, sand, foaming agent, and water are the main ingredients used to produce foamed concrete. As such, the sand-binder ratio and water-binder ratio used for this study were 2:1 and 0.55 , respectively, while the foam was pregenerated using 1:20 (foaming agent to water) ratio. The sand, used as fine aggregates, was sieved through 4.75 $\mu \mathrm{m}$ sieve and oven-dried before being packed in plastic bags to prevent moisture absorption. POFA and ESP, which are the main waste materials that are to be investigated, were used as SCMs in the study.

The POFA was sieved through $300 \mu \mathrm{m}$ and oven-dried for 24 hours at a temperature of $105 \pm 5{ }^{\circ} \mathrm{C}$ to remove any impurities and moisture (Alnahhal et al., 2018; Zeyad et al., 2017; Liu et al., 2014) that the source which was collected from Ban Dung Palm Oil Mill, Parit Sulong, Malaysia, may contain. Afterwards, the POFA was ground using the Los Angeles Abrasion Machine for 2 hours. ESP was obtained through the processing of locally collected eggshells. The collected raw eggshells were washed and then oven-dried for 24 hours at a temperature of $105 \pm 5^{\circ} \mathrm{C}$ to remove moisture (Yusuff, 2017; Ghani et al., 2012). The moisture-dried eggshells were then ground using Los Angeles Abrasion Machine for 2 hours. Grinding waste materials has been found to be an efficient way to transform these large particles into small sizes and homogeneous powders such as cement and to improve mechanical-chemical activation (Jhatial et al., 2020b).

\section{DESIGN}

In this experimental investigation, the GFC was prepared with a dry target density of $1800 \mathrm{~kg} / \mathrm{m}^{3}$. The foamed concrete (FC control) specimen (with no cement replacement) was cast for comparison. The variables in this study were the cement replacement level with POFA, whereby the POFA content varied from $15 \%$ to $35 \%$ with an increment of 5\%, while ESP content was kept constant at 5\%, by weight of cement. The mix proportion is tabulated in Table 1.

Table 1. Mix Proportion of GFC.

\begin{tabular}{|c|c|c|c|c|c|c|c|c|c|c|c|}
\hline \multirow{2}{*}{$\begin{array}{c}\text { Mix } \\
\text { Proportion }\end{array}$} & \multicolumn{3}{|c|}{$\%$ of Binder } & \multicolumn{4}{c|}{ Mix proportions (kg/m ${ }^{3}$} & \multicolumn{2}{c|}{$\begin{array}{c}\text { Quantities Required to } \\
\text { Produce Foam (litres) }\end{array}$} \\
\cline { 2 - 12 } & OPC & POFA & ESP & OPC & POFA & ESP & Sand & Water & $\begin{array}{c}\text { Foaming } \\
\text { Agent } \\
\text { Weam } \\
\text { Wequired } \\
\text { in the mix }\end{array}$ \\
\hline FC Control & $100 \%$ & $0 \%$ & $0 \%$ & 535.2 & 0 & 0 & 1070.4 & 294.4 & 0.30 & 6.06 & 125.06 \\
\hline GFC15P5E & $80 \%$ & $15 \%$ & $5 \%$ & 428.2 & 80.3 & 26.8 & 1070.4 & 294.4 & 0.30 & 6.06 & 125.06 \\
\hline GFC20P5E & $75 \%$ & $20 \%$ & $5 \%$ & 401.4 & 107 & 26.8 & 1070.4 & 294.4 & 0.30 & 6.06 & 125.06 \\
\hline GFC25P5E & $70 \%$ & $25 \%$ & $5 \%$ & 374.7 & 133.8 & 26.8 & 1070.4 & 294.4 & 0.30 & 6.06 & 125.06 \\
\hline GFC30P5E & $65 \%$ & $30 \%$ & $5 \%$ & 347.9 & 160.6 & 26.8 & 1070.4 & 294.4 & 0.30 & 6.06 & 125.06 \\
\hline GFC35P5E & $60 \%$ & $35 \%$ & $5 \%$ & 321.1 & 187.3 & 26.8 & 1070.4 & 294.4 & 0.30 & 6.06 & 125.06 \\
\hline
\end{tabular}


Firstly, the binder materials (OPC, POFA, and ESP) and sand were dry-mixed thoroughly for about 5 minutes in the concrete mixer. Water was added gradually, and the materials were left to mix for another 5 minutes. Then, the pregenerated foam was added gradually to the mix, and upon completion of mixing, the GFC was poured into moulds and left for 24 hours before demoulding them and starting of the specified air-curing period in the laboratory at room temperature.

\section{CHEMICAL AND PHYSICAL PROPERTIES}

The chemical composition of binder materials (OPC, POFA, and ESP) was determined by X-Ray Fluorescence (XRF) in accordance with ASTM C114-15. The physical properties of binder materials, which were determined, include particle size distribution, specific surface area, morphology, and specific gravity.

\section{FLOWABILITY PROPERTY}

J-Ring test was conducted on each mix to determine the effect of POFA and ESP on the flowability of foamed concrete. The J-Ring test was performed according to ASTM C1621/C1621M-17, in which j-ring flow and slump flow were determined for each mix by measuring two diameters $\left(\mathrm{d}_{1}\right.$ and $\left.\mathrm{d}_{2}\right)$.

\section{MECHANICAL STRENGTHS}

After being air-cured in the laboratory at room temperature for 28 days, the mechanical strengths determined in this study included compressive and splitting tensile strengths. Cubical specimens of $100 \mathrm{~mm}$ were prepared for compressive strength testing, while cylindrical specimens of $100 \mathrm{~mm}$ x $200 \mathrm{~mm}$ were prepared to determine the splitting tensile strength, and both were tested according to guidelines provided in BS EN 12390-3:2009 and BS EN 12390-6:2009, respectively. A linear strength relationship was developed between the compressive and splitting tensile strengths of GFC.

\section{THERMAL PERFORMANCE}

To understand and study the thermal performance of GFC when incorporating POFA and ESP, surface temperature and thermal conductivity tests were conducted. In order to determine the surface temperature of the GFC, $300 \mathrm{x} 300 \mathrm{x}$ $50 \mathrm{~mm}$ panels were used. The specimens, which were air-cured for 28 days, were insulated on all sides except on the top with polystyrene sheets, such that the heat transfer due to solar radiation was 1-dimensional. Infrared thermometer (Jhatial et al., 2020c; Bevilacqua et al., 2017) was used to record the surface temperature of the specimens from 10:00 A.M. to 4:00 P.M. All the readings were taken at intervals of 15 minutes for three consecutive days (Anting et al., 2018). The surface temperature of each specimen was taken at five random points on the exposed surface. The average was taken as the surface temperature of the sample. The intensity of solar radiation and the ambient temperature of the surrounding were also measured using pyranometer and globe, respectively, while, being simultaneously recorded using data logger, the surface temperature setup is shown in Figure 1.

Since the surface temperature was a nondestructive test method, the same panels were used for thermal conductivity testing using the guarded hot plate method as prescribed in BS EN 12664:2001, and the procedure is explained by the authors in their earlier works (Jhatial et al., 2020c; Jhatial et al., 2020d). 


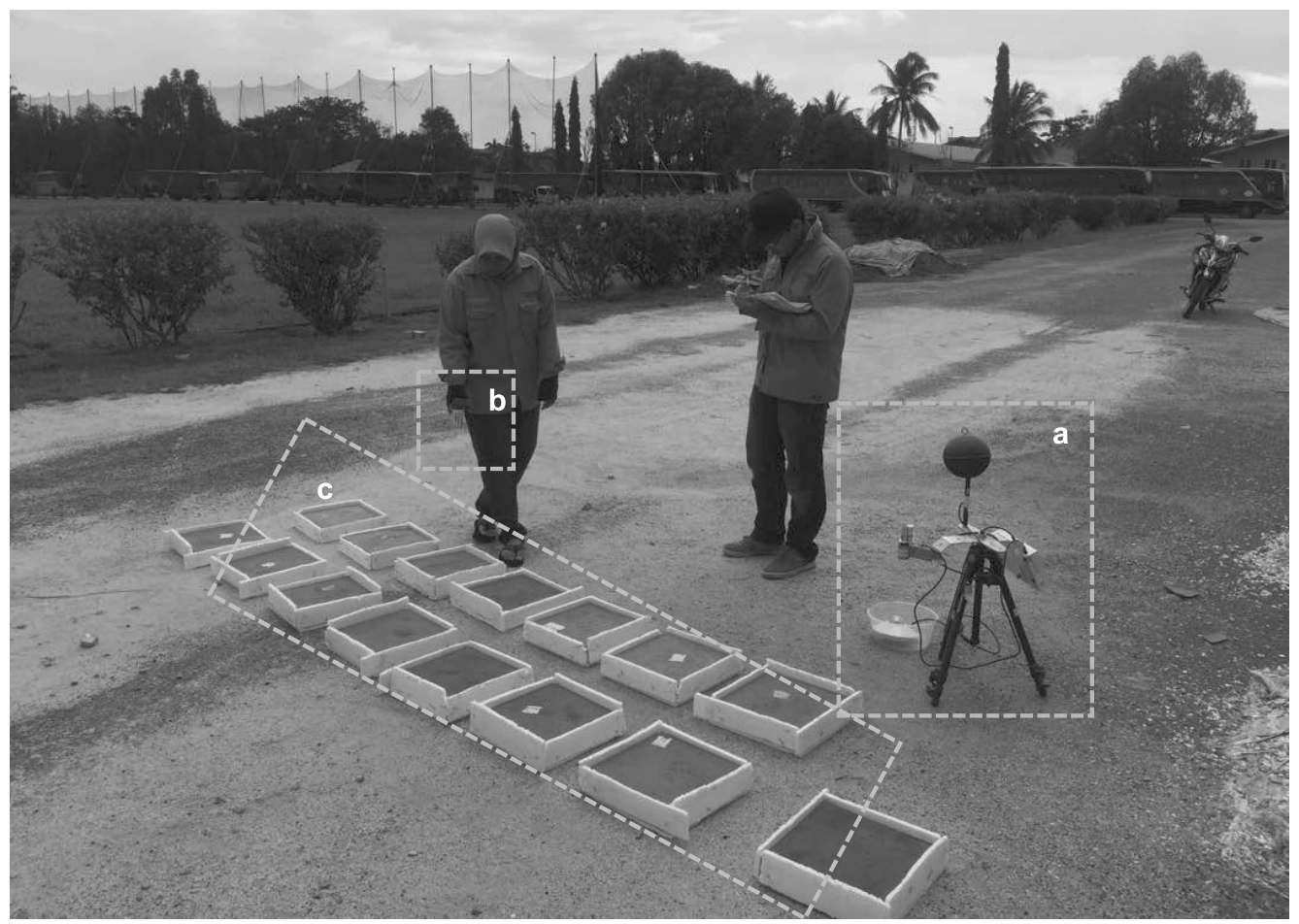

Figure 1. Surface Temperature Testing Set-up consisting of (a) Globe to measure ambient temperature, Pyranometer to measure the intensity of solar radiation and datalogger to record these values (b) infrared thermometer to measure the surface temperature on the (c) samples.

\section{RESULTS AND DISCUSSION}

\section{CHEMICAL AND PHYSICAL PROPERTIES:}

Figure 2 illustrates the particle size distribution (PSD) curves of ESP, POFA, and OPC. The curves of ESP and POFA indicate that the grinding process produced well-graded material. Furthermore, more than $90 \%$ of ESP particles were able to $45 \mu \mathrm{m}$ sieve and achieved a mean size of $11.4 \mu \mathrm{m}$. As for the POFA particles, approximately $84.23 \%$ were able to pass through $45 \mu \mathrm{m}$, and it achieved a mean size of $19.6 \mu \mathrm{m}$, while, on the finer hand, roughly $16.63 \%$ and $6.29 \%$ of ESP and POFA, respectively, were found to be less than $2 \mu \mathrm{m}$. The OPC had $7.29 \%$ finer than $2 \mu \mathrm{m}$ of particles and 96.47 percent finer than $45 \mu \mathrm{m}$. The average particle size of OPC was $18.4 \mu \mathrm{m}$.

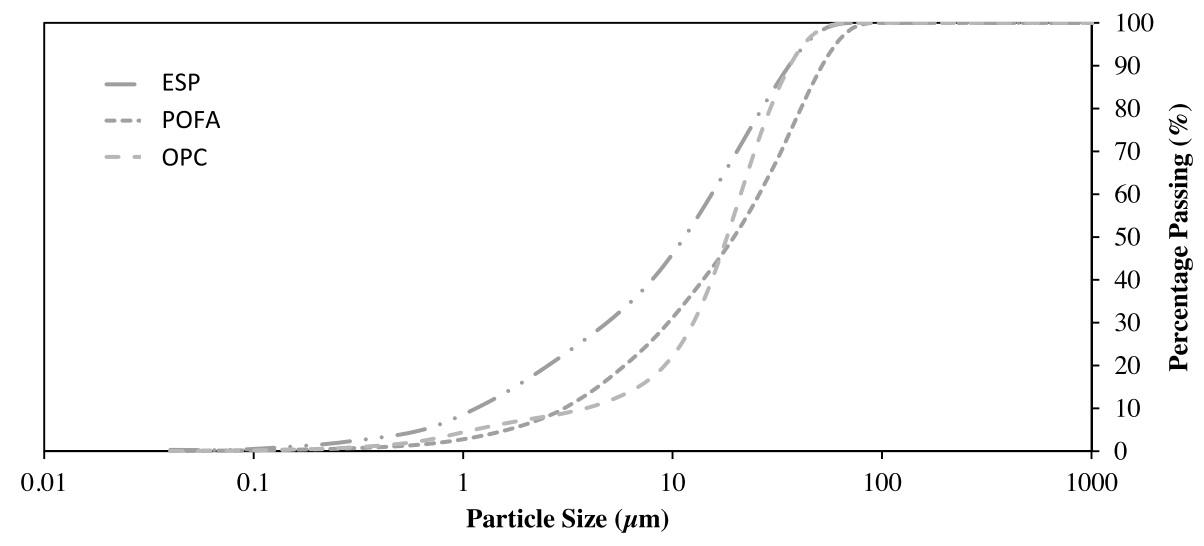

Figure 2. Particle Size Analysis (Jhatial et al., 2020e). 
This indicates that the ESP and POFA could be used as a binder due to the similar PSD as cement. Furthermore, this may be supported by the specific surface area (SSA) of the materials as shown in Table 2. The SSA of POFA (4532 $\left.\mathrm{cm}^{2} / \mathrm{g}\right)$ was almost identical to OPC $\left(4870 \mathrm{~cm}^{2} / \mathrm{g}\right)$; however, for ESP, the SSA was much higher $\left(9740 \mathrm{~cm}^{2} / \mathrm{g}\right)$. The high SSA of ESP can be attributed to the open porosity of the ground ESP (Jhatial et al., 2020e). The SSA measurements include not only the external, but also the open internal SSA of the particles. Besides that, it is observed that the specific gravity of POFA and ESP was significantly lower than the specific gravity of OPC. Being organic materials, POFA and ESP contain higher voids or pores within the matrix of material, and the presence of these voids greatly influences the specific gravity.

Table 2. Physical Properties of OPC, POFA, and ESP (Jhatial et al., 2020e).

\begin{tabular}{|c|c|c|c|}
\hline & OPC & POFA & ESP \\
\hline \% Passing Through $45 \mu \mathrm{m}($ no. 325) sieve & 96.47 & 84.23 & 95.95 \\
\hline Median Particle Size, d50 $(\mu \mathrm{m})$ & 18.4 & 19.6 & 11.4 \\
\hline Specific Surface Area $(\mathrm{SSA})\left(\mathrm{cm}^{2} / \mathrm{g}\right)$ & 4870.81 & 4532.38 & 9740.14 \\
\hline Specific Gravity & 3.14 & 2.12 & 2.34 \\
\hline
\end{tabular}

Figure 3 shows the particle morphology of cement, shows nonspherical particle, and has an irregular shape, which seems to be a stone shape. This stone-like shape leads to stronger particle interlocking and thus increases the surface friction and viscosity of cement paste, whereas the particle morphology of ESP, as shown in Figure 4, shows that the particles are irregular, varying from round to popcorn shaped like particles. On the other hand, it can be seen in Figure 5 that POFA has angular, as well as irregularly shaped, particles with some porous particles. It can also be observed that the particle size is much larger than that of OPC and ESP, concurring well with the observation of median particle size and \% particles finer than $45 \mu \mathrm{m}$ reported earlier.

The chemical element analysis through XRF is tabulated in Table 3, by summing the values of three elements $\left(\mathrm{SiO}_{2}\right.$, $\mathrm{Al}_{2} \mathrm{O}_{3}$, and $\mathrm{Fe}_{2} \mathrm{O}_{3}$ ), the POFA can be categorized as class - C pozzolan according to ASTM C618-19. Furthermore, the results also indicate that ESP contains significantly high amount of $\mathrm{CaO}$, which could potentially create additional $\mathrm{Ca}[\mathrm{OH}]_{2}$ when it encounters water and thus could be consumed during the pozzolanic reaction. The physical properties and chemical compositions of POFA and ESP suggest that these waste materials can be utilized as binder material to partially replace cement, which could moderate the use and production of cement, as well as lowering $\mathrm{CO}_{2}$ gas emissions.
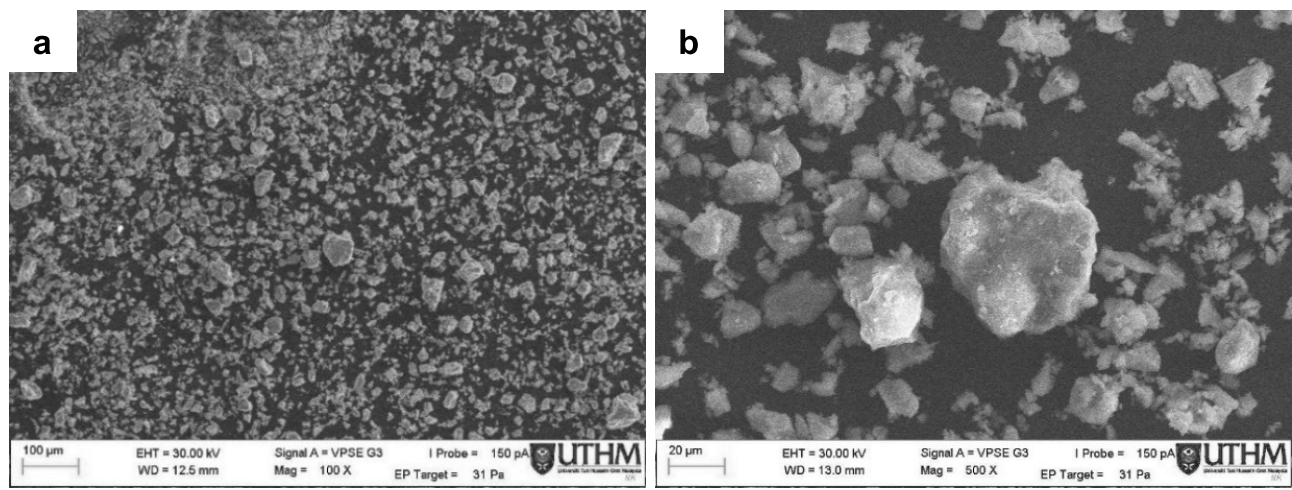

Figure 3. Particle Morphologies of OPC at (a) 100X (b) 500X magnification. 

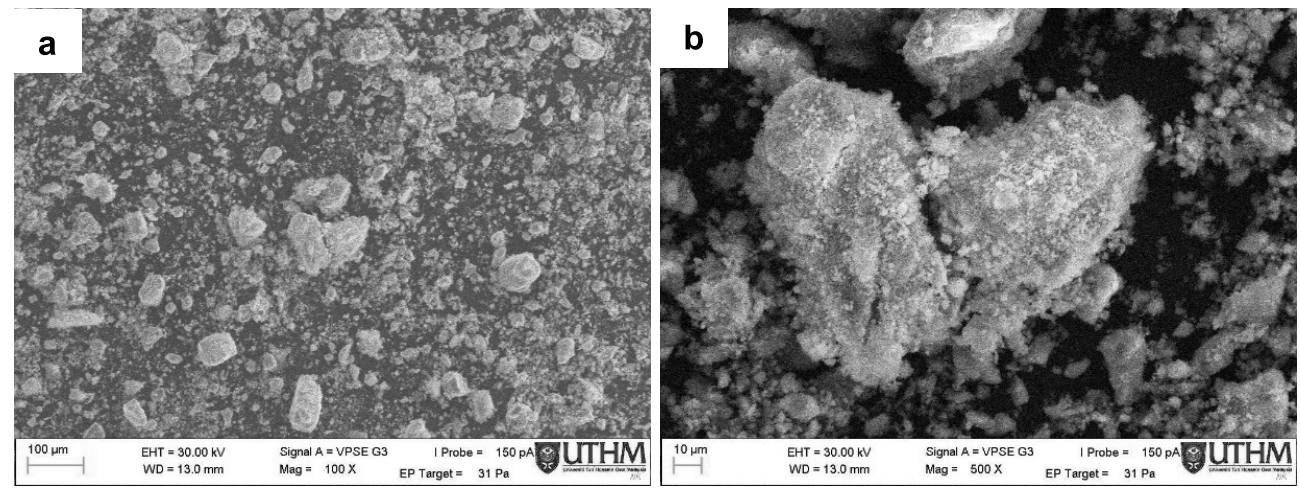

Figure 4. Particle Morphologies of ESP at (a) 100X (b) 500X magnification.
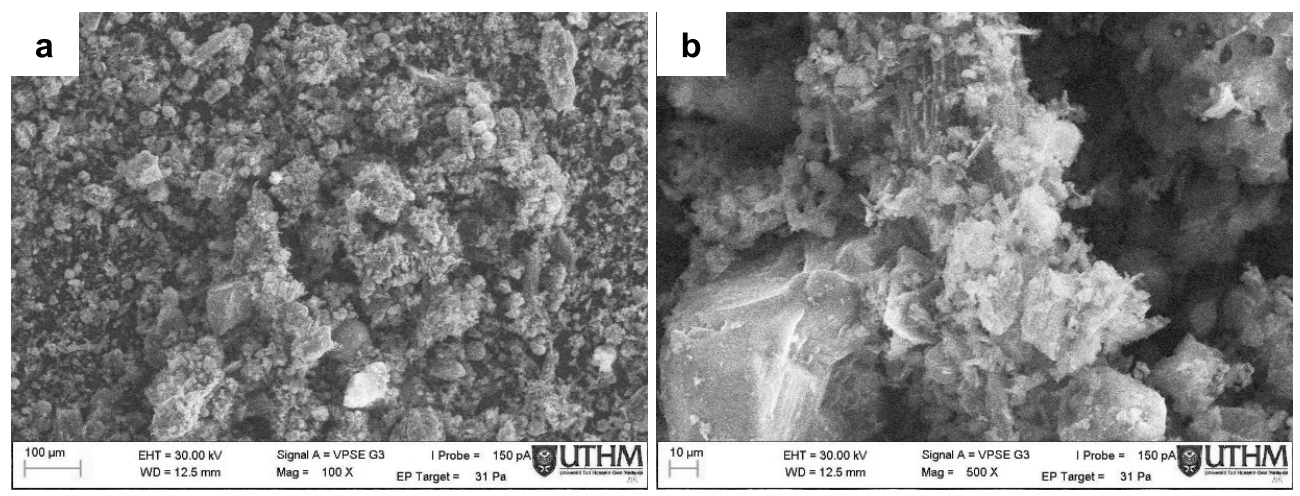

Figure 5. Particle Morphologies of POFA at (a) 100X (b) 500X magnification.

Table 3. Chemical Analysis of OPC, POFA and ESP (Jhatial et al., 2020e).

\begin{tabular}{|c|c|c|c|c|c|c|c|c|c|}
\hline & $\mathbf{C a O}$ & $\mathrm{SiO}_{2}$ & $\mathrm{Al}_{2} \mathbf{O}_{3}$ & $\mathbf{F e}_{2} \mathbf{O}_{3}$ & $\mathbf{M g O}$ & $\mathbf{K}_{2} \mathbf{O}$ & $\mathbf{C}$ & $\mathbf{S O}_{3}$ & $\mathbf{P}_{2} \mathbf{O}_{5}$ \\
\hline OPC & $63.95 \%$ & $20.61 \%$ & $3.95 \%$ & $3.46 \%$ & $1.93 \%$ & - & - & $3.62 \%$ & - \\
\hline POFA & $8.10 \%$ & $51.83 \%$ & $2.32 \%$ & $7.60 \%$ & $3.13 \%$ & $13.72 \%$ & $0.28 \%$ & $2.23 \%$ & $4.30 \%$ \\
\hline ESP & $88.76 \%$ & $1.63 \%$ & - & $0.05 \%$ & $0.91 \%$ & $0.24 \%$ & - & $0.81 \%$ & - \\
\hline
\end{tabular}

\section{FLOWABILITY PROPERTY}

The foamed concrete is a well-known type of concrete, which is highly flowable and self-levelling; this is proven in the workability test (Kamaruddin et al., 2018). The results tabulated in Table 4 indicated that the control sample of foamed concrete (FC control) achieved the maximum flowability. But with the gradual increase in cement replacement, the flowability decreased significantly. The flow of foamed concrete was restricted when POFA and ESP were added, and the high surface area of both POFA and ESP particles is the main reason behind this restriction, which requires a significantly higher amount of water to achieve ease in movement and rolling of particles over each other. Maximum decrease in flowability was observed for the mix, which contained combined high content $(40 \%)$ cement replacement, as the high content of POFA and ESP absorbs more water. Though the flowability was reduced with increase in POFA and ESP contents, the difference between slump flow and j-ring flow was between 0 and $25 \mathrm{~mm}$ for all mix proportions, and no visible blockage was observed in any of the mixtures. 
Table 4. Flowability results of GFC (Kamaruddin et al., 2018).

\begin{tabular}{|c|c|c|c|c|c|c|c|c|}
\hline \multirow[b]{2}{*}{ Mix } & \multicolumn{3}{|c|}{ Slump Flow (mm) } & \multicolumn{3}{|c|}{ J-Ring Flow (mm) } & \multirow{2}{*}{$\begin{array}{c}\text { Diff. between } \\
\text { Slump and J-ring } \\
\text { Flow }(\mathbf{m m})\end{array}$} & \multirow{2}{*}{$\begin{array}{l}\text { Type of } \\
\text { Blocking }\end{array}$} \\
\hline & $d_{1}$ & $\mathbf{d}_{2}$ & $\frac{d_{1}+d_{2}}{2}$ & $d_{1}$ & $\mathbf{d}_{2}$ & $\frac{d_{1}+d_{2}}{2}$ & & \\
\hline FC Control & 533 & 528 & 531 & 520 & 520 & 520 & 11 & No Blocking \\
\hline GFC15P5E & 430 & 436 & 432 & 424 & 418 & 421 & 12 & No Blocking \\
\hline GFC20P5E & 398 & 390 & 394 & 385 & 370 & 378 & 16 & No Blocking \\
\hline GFC25P5E & 419 & 415 & 417 & 415 & 390 & 403 & 14 & No Blocking \\
\hline GFC30P5E & 410 & 400 & 405 & 394 & 381 & 388 & 17 & No Blocking \\
\hline GFC35P5E & 407 & 391 & 399 & 381 & 376 & 379 & 20 & No Blocking \\
\hline
\end{tabular}

\section{MECHANICAL PROPERTIES}

The average compressive strength results for the GFC specimens is illustrated in Figure 6. In general, the FC control specimen (without waste materials) achieved a compressive strength of $17.1 \mathrm{MPa}$ upon completion of 28 days air-curing. On the other hand, the GFC mixes containing POFA attained improved compressive strength, which could be attributed to the pozzolanic reaction, in which $\mathrm{Ca}[\mathrm{OH}]_{2}$ available from $\mathrm{OPC}$, as well as from ESP, was consumed in developing additional C-S-H gels. The compressive strength could be enhanced up to $32.2 \%$ depending on the POFA and ESP contents.

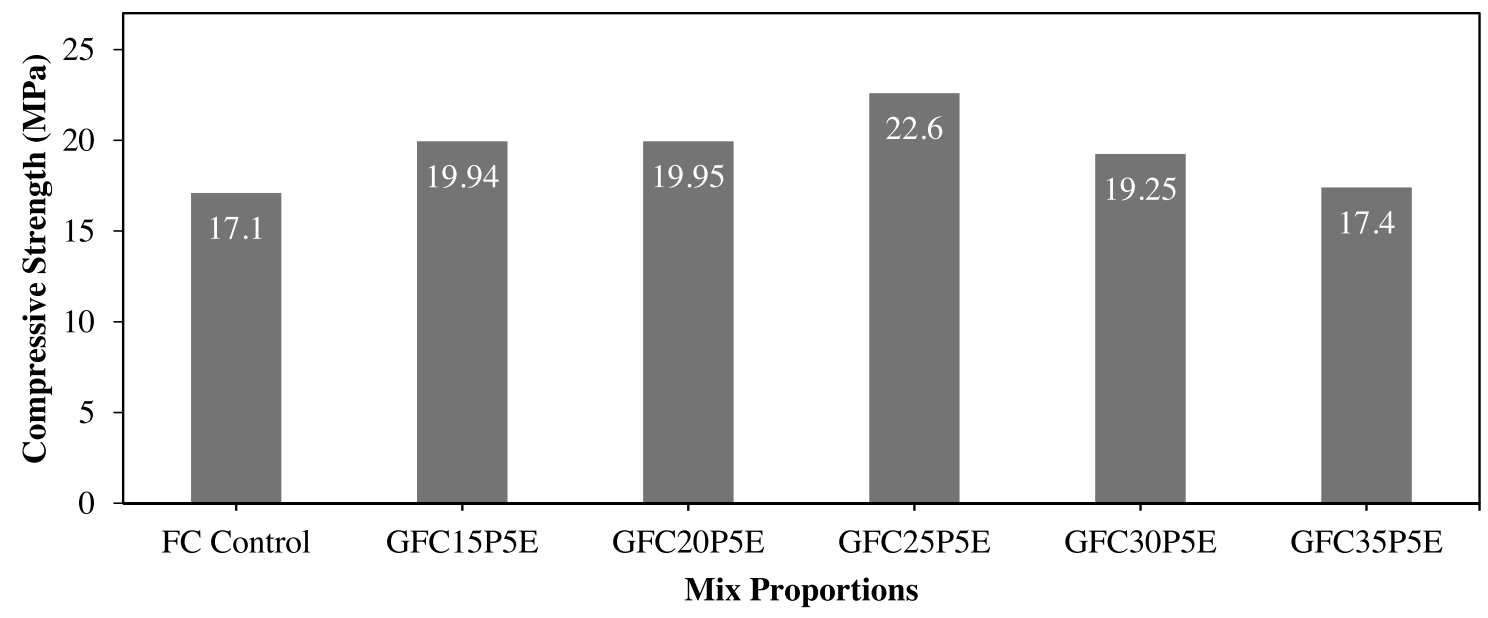

Figure 6. Average Compressive Strength of GFC.

Generally, the optimum of cement replacement by POFA is about 10-20\% (Tonnayopas et al., 2016; Munir et al., 2015; Lim et al., 2013; Chindaprasirt et al., 2007), and this is limited by dilution effect, whereby reduced cement content limits the pozzolanic activity of POFA, and thus the gain in strength. However, in this research, it was found that the optimum content of POFA could be raised to $25 \%$, and this could be due to the addition of $\mathrm{CaO}$ provided by ESP. As there is a high amount of calcium available from the ESP, a further pozzolanic reaction can be facilitated to develop more C-S-H gels and enhance the strength of GFC. 
Figure 7 shows the splitting tensile strength of GFC. The maximum tensile strength was recorded by GFC20P5E (2.61 MPa), which was $13.48 \%$ higher than the FC control. Further, an increase in POFA content beyond $25 \%$ was observed, the tensile strength decreased significantly to $1.78 \mathrm{MPa}$, and a reduction of $14 \%$ was observed compared to the FC control. This is in line with the observation of the compressive strength results obtained for the specimens.

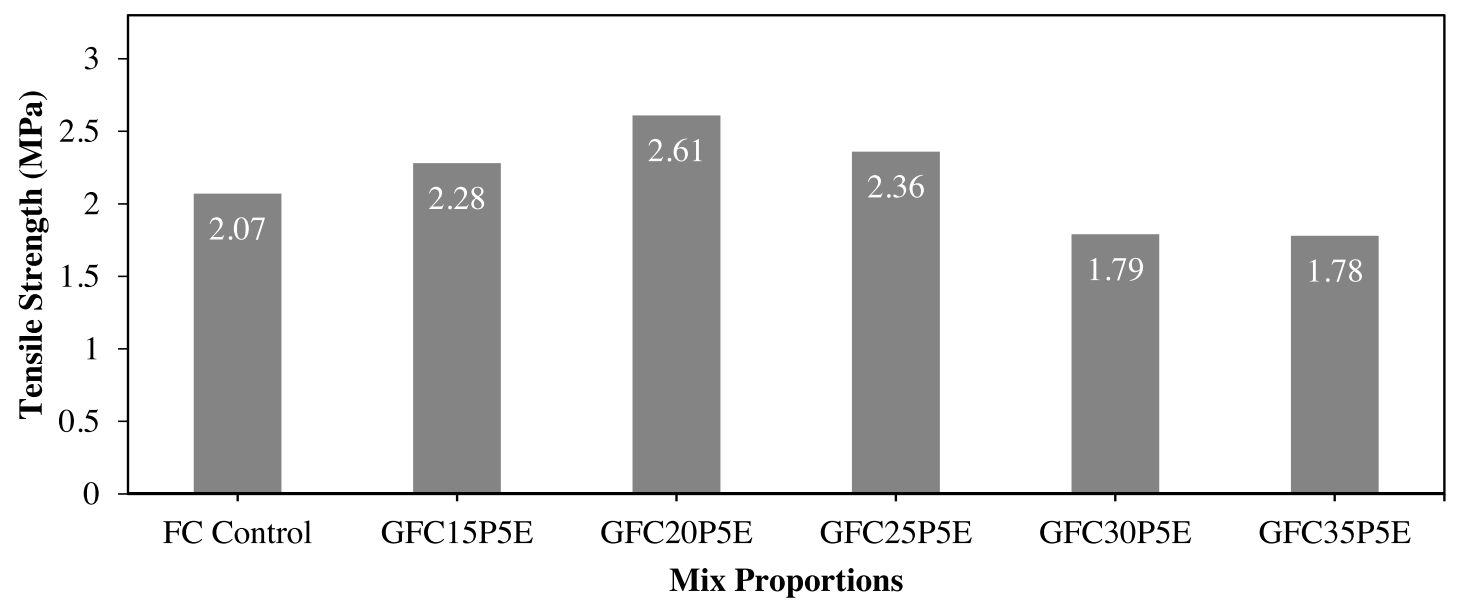

Figure 7. Average Tensile Strength of GFC.

A linear relationship between compressive and splitting tensile strength behaviour of foamed concrete incorporating different proportions of POFA and ESP, at the age of 28 days, was developed through statistical procedures. The $\mathrm{R}^{2}$ value, determined through regression curve analysis, was considered as the relationship coefficient in this experimental work. The regression curve line shows the relationship between the independent variable (compressive strength) and the dependent variable (splitting tensile strength) as shown in Figure 8. The developed equation, along with the $\mathrm{R}^{2}$ coefficients, is provided as follows:

$f_{t}=0.0979 f_{c}+0.2507 \quad R^{2}=0.3543$

where

$\mathrm{f}_{\mathrm{c}}$ : the compressive strength (MPa);

$\mathrm{f}_{\mathrm{t}}$ : the split tensile strength (MPa).

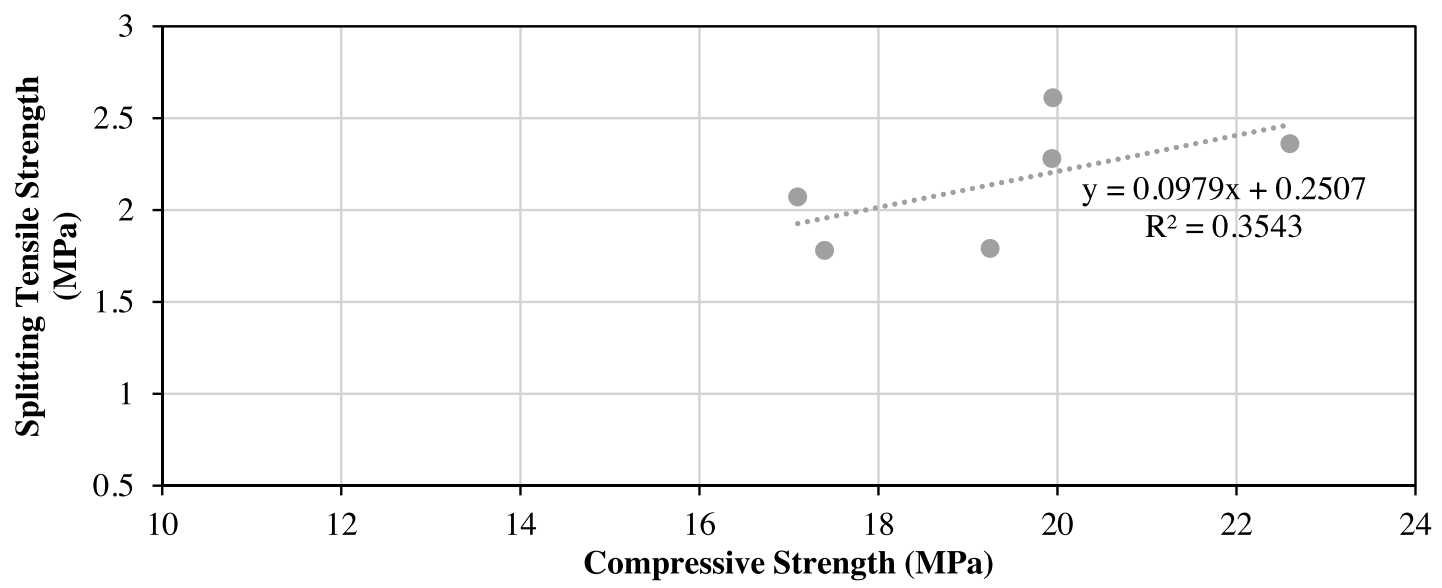

Figure 8. Linear Strength Relationship of GFC. 


\section{THERMAL PERFORMANCE}

Thermal conductivity is the property of a material, which measures the heat passing through the material. A lower thermal conductivity value indicates better thermal insulation of material. The average thermal conductivity value of GFC specimens is shown in Figure 9. For the FC control, the measured thermal conductivity was $0.82 \mathrm{~W} / \mathrm{mK}$. The thermal conductivity was found to be lowered in the mixes with 15\% POFA $+5 \%$ ESP and 30\% POFA + 5\% ESP.

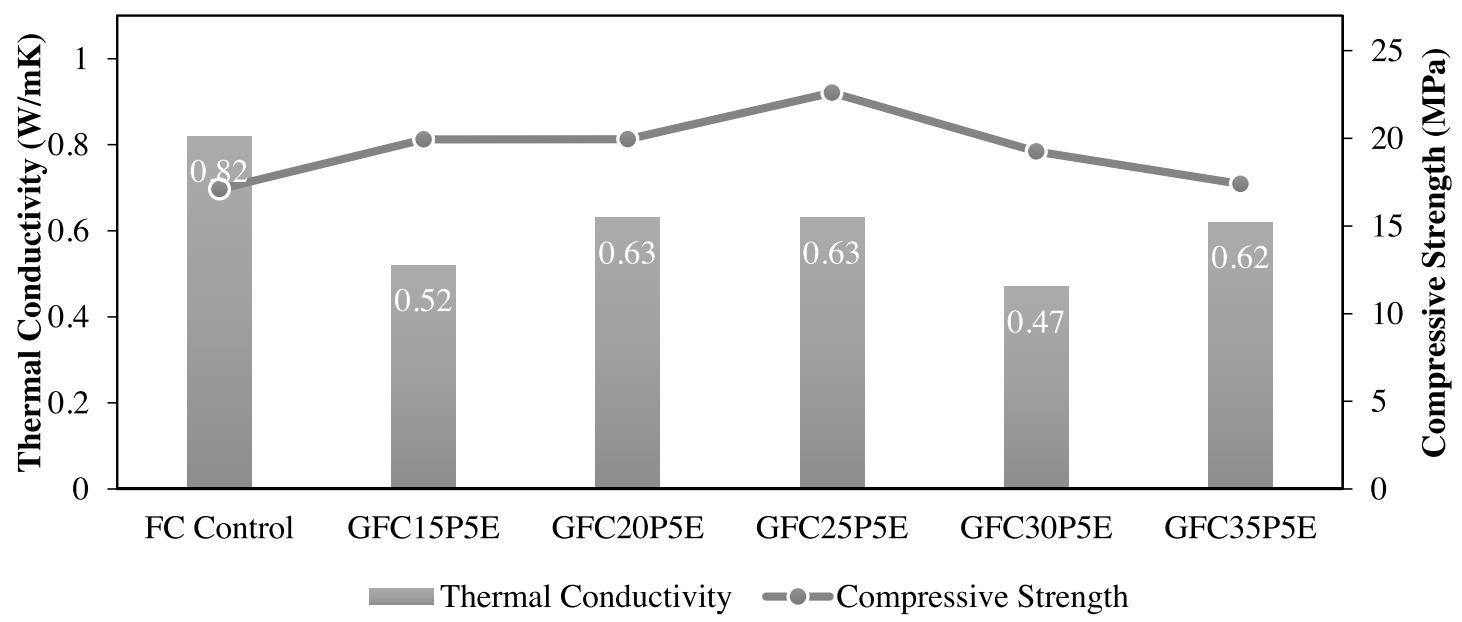

Figure 9. Average Thermal Conductivity of GFC.

The lowest measured thermal conductivity value of $0.47 \mathrm{~W} / \mathrm{mK}$ was obtained from the mix GFC30P5E, which represents a reduction ranging up to $42.68 \%$ compared to the control. The decline in thermal conductivity of mixes GFC15P5E could be attributed to the dilution effects caused by POFA and ESP replacement of cement, as well as the porosity of these wastes. As the POFA content increased up to $25 \%$, the effectiveness of pozzolanic reaction induced in the presence of POFA and ESP could have densified the microstructure of the foamed concrete, and hence, the thermal conductivity value did not change significantly compared to the FC control. Further replacement of POFA could have resulted in the presence of more voids due to the increased dilution effect, which corresponds to the reduction in compressive strength of the mix GFC30P5E. The decline in the thermal conductivity with the use of POFA and ESP agrees with a previous study (Mo et al., 2017) that reported reduction ranging from $15 \%$ to $50 \%$ in thermal conductivity when POFA was utilized. A significant drop in thermal conductivity when different waste materials were used as cement replacement has also been reported previously (Demirboga, 2003). The surface temperature, ambient temperature, and intensity of solar radiation recorded are shown in Figure 10. The summary of surface temperatures readings is also tabulated in Table 5 . 
Table 5. Summary of Surface Temperature.

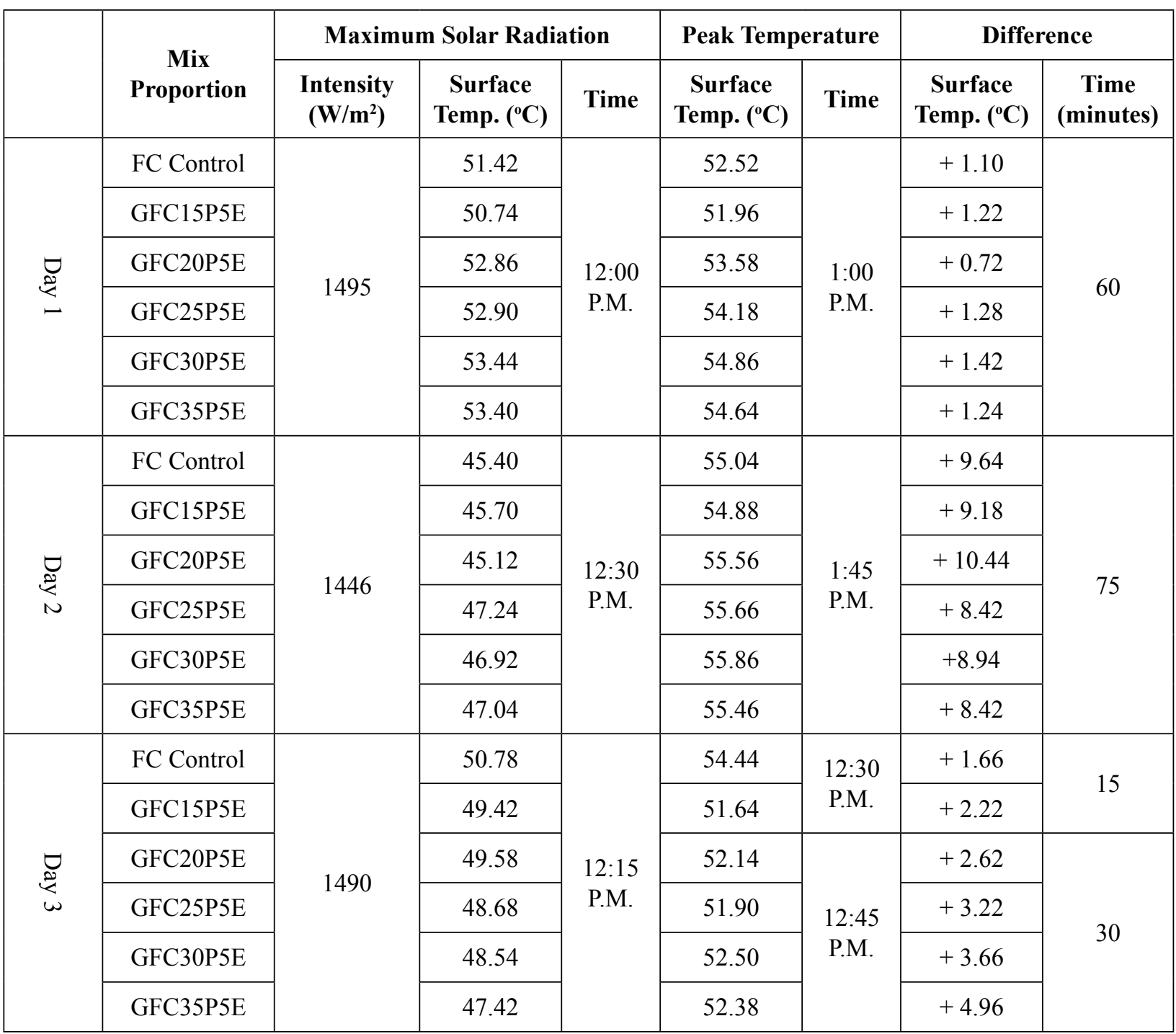

From the data, it is observed that the intensity of solar radiation and the colour of concrete have a significant influence on the surface temperature of concrete. When POFA is incorporated in the foamed concrete, the colour of specimens turned to dark grey, as shown in Figure 11. This allows the sample to absorb solar radiation. Therefore, the effect of the addition of POFA in foamed concrete on the heat absorbed is evident based on the surface temperature readings. It can also be observed that the temperature of the samples did not increase immediately when the intensity of solar radiation was at maximum. It took between 15 and 75 minutes after the maximum solar radiation occurred, in which the surface temperature was at highest. The difference between the temperature when maximum solar radiation occurs and the maximum surface temperature recorded on the specimens also varied, ranging from $0.72{ }^{\circ} \mathrm{C}$ to 10.44 ${ }^{\circ} \mathrm{C}$. It should be noted that samples containing $15 \%$ to $25 \%$ POFA along with $5 \%$ ESP absorbed significantly less amount of solar radiation compared to $30 \%$ POFA. This range of POFA content can, therefore, be determined as the limit to prevent excessive absorption of heat while encouraging the sustainable use of the POFA and ESP waste in the GFC. 


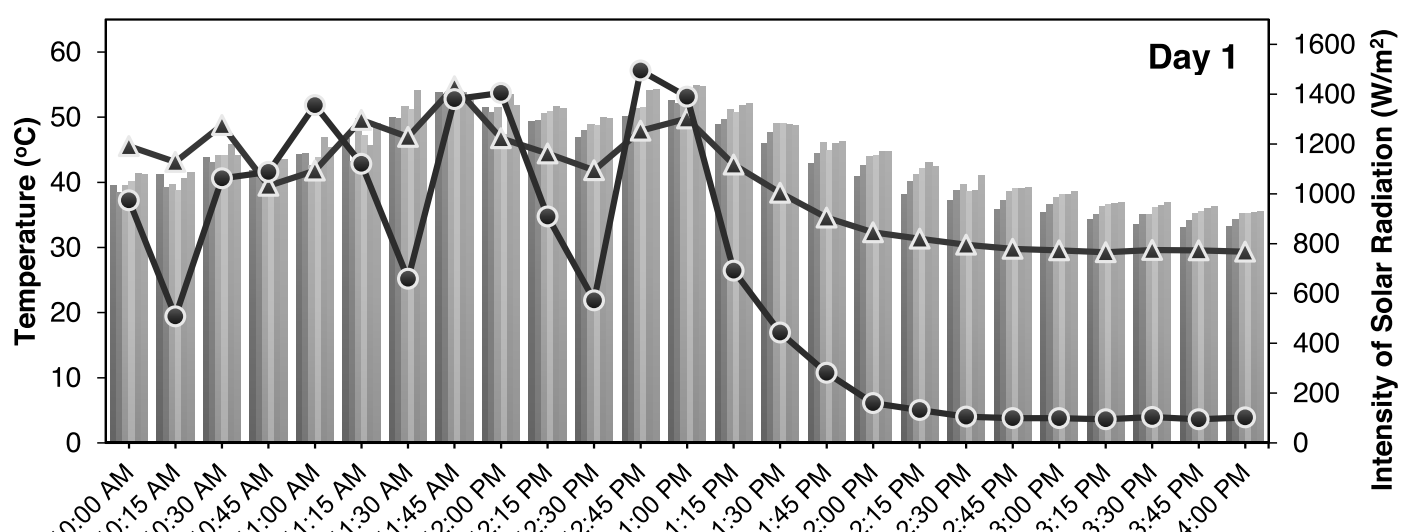

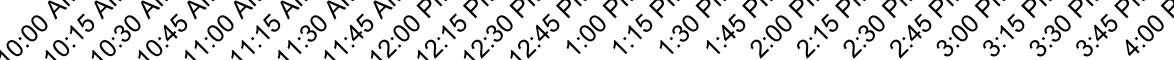
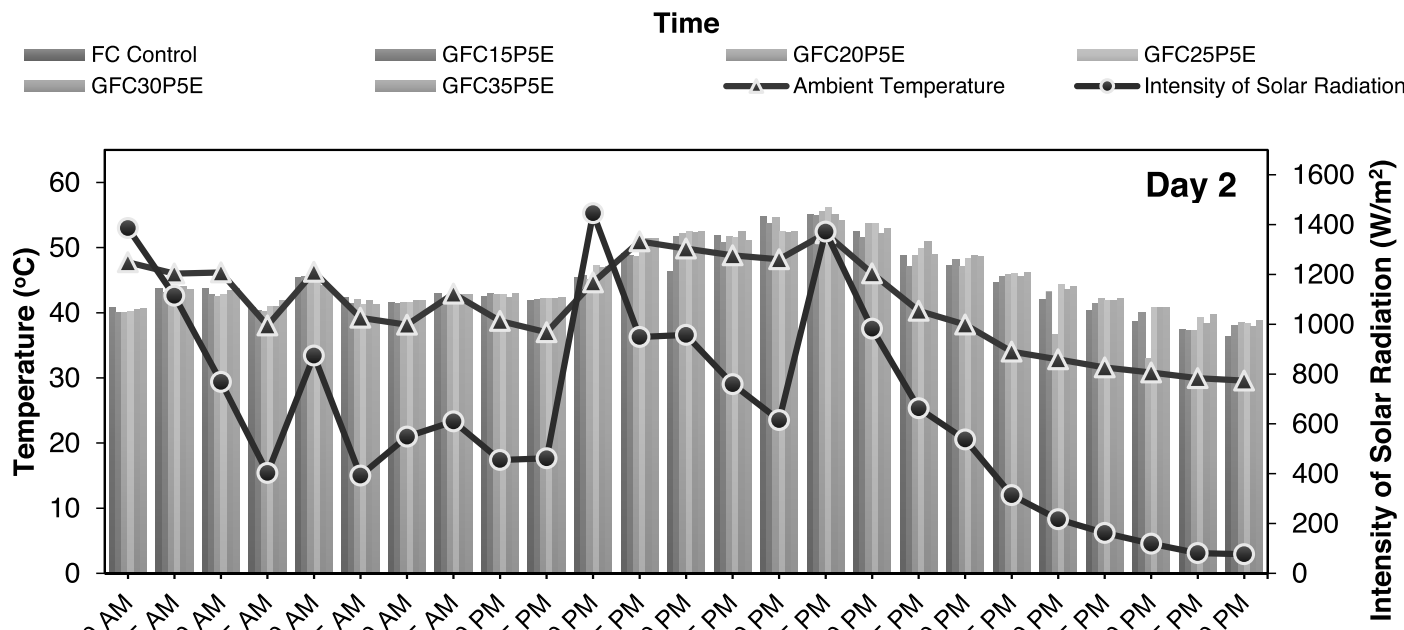

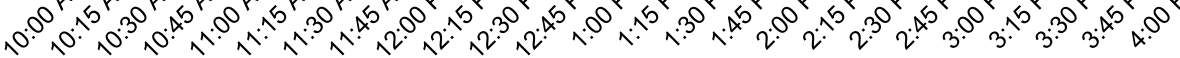

\section{Time}

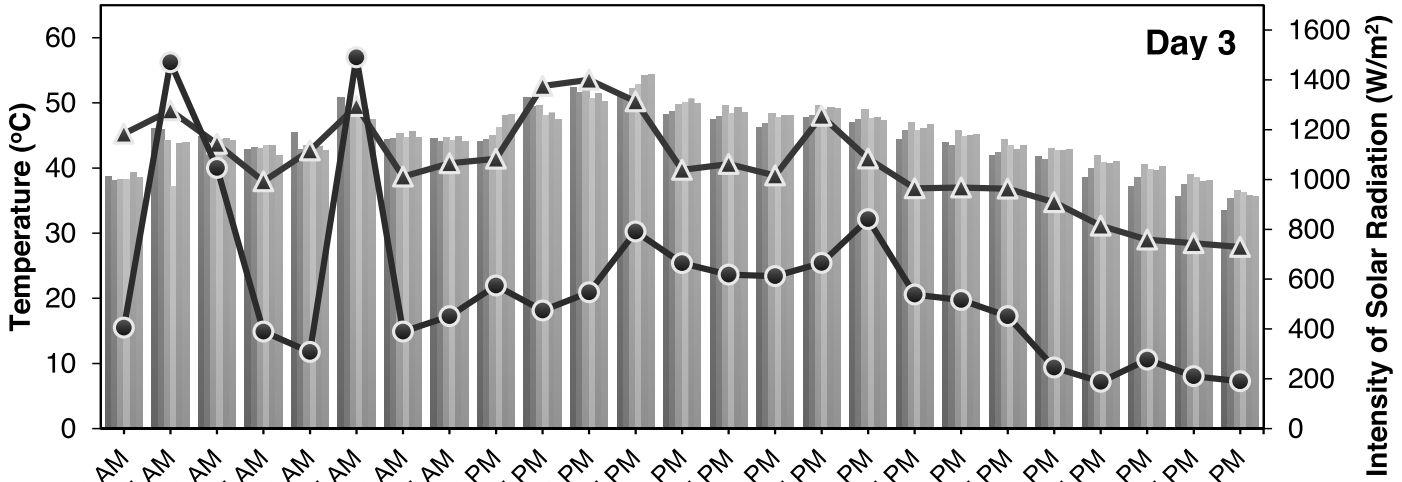

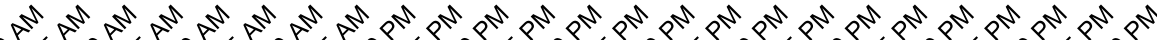

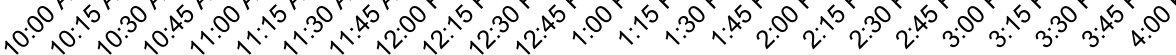

Time

Figure 10. Surface Temperature Results. 


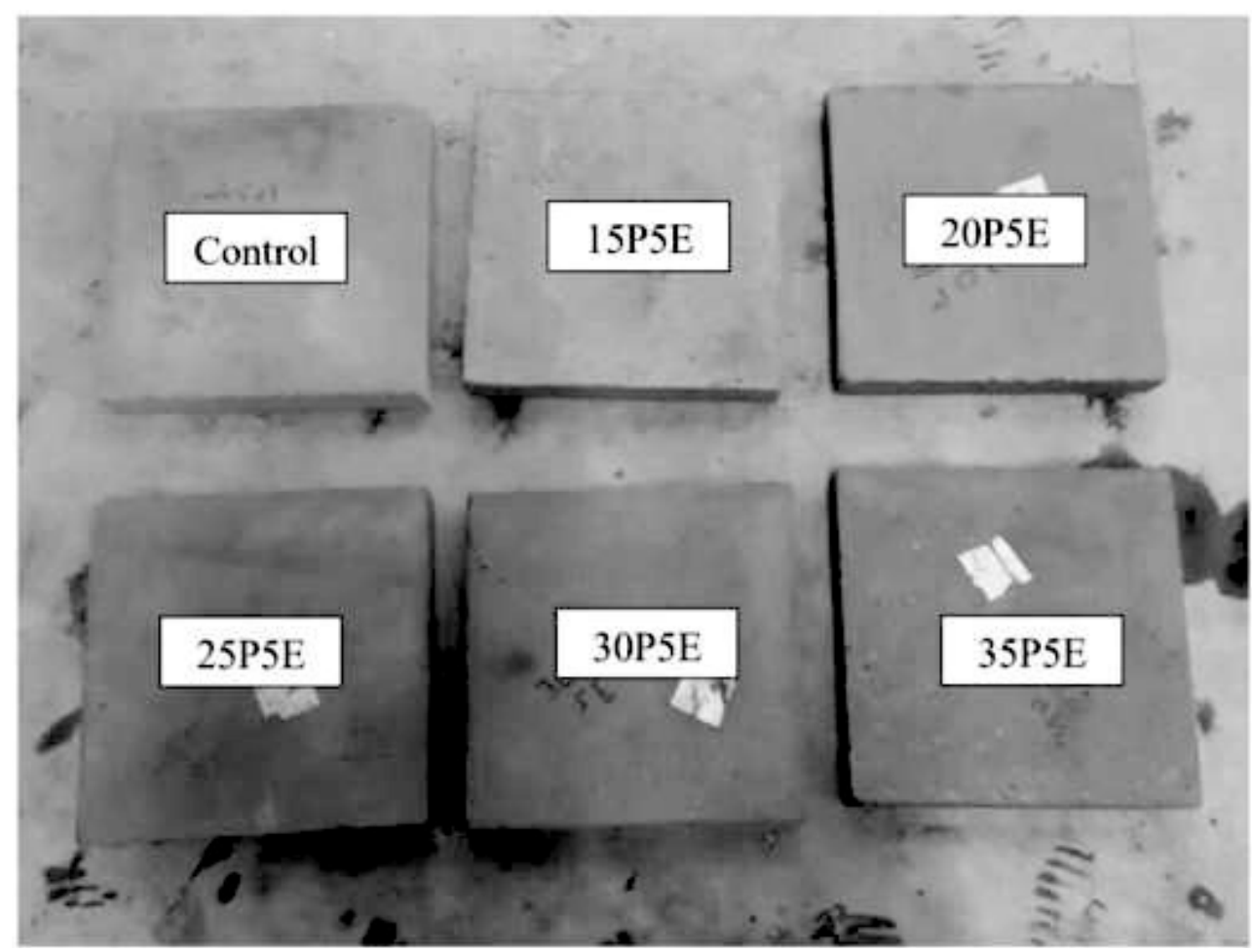

Figure 11. Change in colour of specimens with addition of ESP and POFA.

\section{CONCLUSION}

This study was conducted to highlight the potential combined utilization of POFA and ESP. It was determined that POFA and ESP are potential alternative binders to cement and could be utilized as partial cement replacement material. Though foamed concrete is a well-known thermal insulator, interestingly, it was also observed that the combined utilization of POFA and ESP could further thermally insulate the concrete. The following conclusions were made:

1. Locally available agroindustrial wastes, namely, POFA and ESP, have the potential to be utilized as cement replacement material in developing green and sustainable foamed concrete.

2. The mechanical strengths (compressive and splitting tensile strengths) were the highest in the foamed concrete with POFA content of $20-25 \%$ in combination of $5 \%$ ESP.

3. At $30 \%$ POFA content along with $5 \%$ ESP, the foamed concrete had the lowest thermal conductivity compared to the control sample of similar target density.

4. Use of POFA altered the colour of concrete from light grey to dark, causing it to absorb a greater amount of heat. Thus, the POFA content is recommended to be limited between $15 \%$ and $25 \%$ in the developed foamed concrete.

Based upon the results, the mix, which contained 25\% POFA and 5\% ESP, in total 30\% cement replacement, was found to be optimum as it achieved higher mechanical strengths, as well as relatively lower thermal conductivity value compared to control sample. As for the mix containing 15\% POFA and 5\% ESP, it is true that thermal conductivity is the most lowest amongst all mixes, and it too has relatively higher mechanical strengths, yet the main aim was to reduce the cement content to the maximum without incurring loss in strength, and with the mix of $15 \%$ POFA and $5 \%$ ESP, only $20 \%$ cement replacement could be achieved, while, with $25 \%$ POFA and 5\% ESP, a $30 \%$ cement replacement could be achieved. 


\section{ACKNOWLEDGMENT}

This research was supported by Ministry of Higher Education (MOHE) through Fundamental Research Grant Scheme for Research Acculturation of Early Career Researchers (RACER/1/2019/TK06/UTHM/1) and Universiti Tun Hussein Onn Malaysia (UTHM) through GPPS-H684.

\section{REFERENCES}

Abdullah, K., Hussin, M.W., Zakaria, F., Muhamad, R., Hamid, Z.A. 2006. POFA: A potential cement replacement material in aerated concrete. Proceedings of the 6th Asia-Pacific Conference on Structural Engineering and Construction, Kuala Lumpur, Malaysia, September 5-6: 132-140.

Alnahhal, M.F., Alengaram, U.J., Jumaat, M.Z., Abutaha, F., Alqedra, M.A., Nayaka, R.R. 2018. Assessment on engineering properties and $\mathrm{CO} 2$ emissions of recycled aggregate concrete incorporating waste products as supplements to Portland cement. Journal of Cleaner Production, 203: 822-835. https://doi.org/10.1016/j.jclepro.2018.08.292

Anting, N., Din, M.F.M., Iwao, K., Ponraj, M., Siang, AJLM, Yong, L.Y., Prasetijo, J. 2018. Optimizing of near infrared region reflectance of mix-waste tile aggregate as coating material for cool pavement with surface temperature measurement. Energy and Buildings, 158: 172-180. https://doi.org/10.1016/j.enbuild.2017.10.001

Assi, L., Carter, K., Deaver, E.E., Anay, R., Ziehl, P. 2018. Sustainable concrete: Building a greener future. Journal of Cleaner Production, 198: 1641-1651. https://doi.org/10.1016/j.jclepro.2018.07.123

ASTM C114-15. Standard Test Methods for Chemical Analysis of Hydraulic Cement, ASTM International, West Conshohocken, PA.

ASTM C1621 / C1621M-17. Standard Test Method for Passing Ability of Self-Consolidating Concrete by J-Ring. ASTM International, West Conshohocken, PA.

ASTM C618-19. Standard Specification for Coal Fly Ash and Raw or Calcined Natural Pozzolan for Use in Concrete, ASTM International, West Conshohocken, PA.

Benhelal, E., Zahedi, G., Shamsaei, E., Bahadori, A. 2013. Global strategies and potentials to curb CO2 emissions in cement industry. Journal of Cleaner Production, 51: 142-161. https://doi.org/10.1016/j.jclepro.2012.10.049

Bevilacqua, P., Mazzeo, D., Bruno, R., Arcuri, N. 2017. Surface temperature analysis of an extensive green roof for the mitigation of urban heat island in southern mediterranean climate. Energy and Buildings, 150: 318-327. https://doi.org/10.1016/j. enbuild.2017.05.081

BS EN 12664:2001. Thermal performance of building materials and products. Determination of thermal resistance by means of guarded hot plate and heat flow meter methods. Dry and moist products of medium and low thermal resistance, British Standards.

BS EN 12390-3:2009. British Standard, Testing hardened concrete. Compressive strength of test specimen, British Standards.

BS EN 12390-6:2009. British Standard, Testing hardened concrete. Tensile splitting strength of test specimens, British Standards.

Chindaprasirt, P., Rukzon, S., Sirivivatnanon, V. 2008. Resistance to chloride penetration of blended Portland cement mortar containing palm oil fuel ash, rice husk ash and fly ash. Construction and Building Materials, 22(5): 932-938. https://doi. org/10.1016/j.conbuildmat.2006.12.001

Chindaprasirt, P., Homwuttiwong, S., Jaturapitakkul, C. 2007. Strength and water permeability of concrete containing palm oil fuel ash and rice husk-bark ash. Construction and Building Materials, 21: 1492-1499. https://doi.org/10.1016/j. conbuildmat.2006.06.015

Demirboga, R. 2003. Influence of mineral admixtures on thermal conductivity and compressive strength of mortar. Energy and Buildings, 35(2): 189-192. https://doi.org/10.1016/S0378-7788(02)00052-X

Dhanalakshmi, M., Sowmya, N., Chandrashekar, A. 2015. A Comparative Study on Egg Shell Concrete with Partial Replacement of Cement by Fly Ash. International Journal of Engineering Research \& Technology, 4(05): 1532-1537.

Embrandiri, A., Singh, R.P., Ibrahim, H.M., Ramli, A.A. 2012. Land application of biomass residue generated from palm oil processing: its potential benefits and threats. The Environmentalist, 32(1): 111-117. https://doi.org/10.1007/s10669-011-9367-0 
Ghani, S.A., Zakaria, A., Shakaff, A.Y., Ahmad, M.N., Abdullah, A.H. 2012. Enhancing conductive polymer performance using eggshell for ammonia sensor. Journal of Physical Science, 23(2): 73-83.

Gowsika D., Sarankokila, S. and Sargunan, K. 2014. Experimental investigation of egg shell powder as partial replacement with cement in concrete. International Journal of Engineering Trends and Technology, 14(2): 65-68. https://doi. org/10.14445/22315381/ijett-v14p214

Hamada, H.M., Jokhio, G.A., Yahaya, F.M., Humada, A.M., Gul, Y. 2018. The present state of the use of palm oil fuel ash (POFA) in concrete. Construction and Building Materials, 175: 26-40. https://doi.org/10.1016/j.conbuildmat.2018.03.227

Jaturapitakkul, C., Kiattikomol, K., Tangchirapat, W., Saeting, T. 2006. Evaluation of the sulfate resistance of concrete containing palm oil fuel ash. Construction and Building Materials, 21(7): 1399-1405. https://doi.org/10.1016/j. conbuildmat.2006.07.005

Jhatial, A.A., Serdar, M., \& Ye, G. 2020a. Review on concrete under combined environmental actions and possibilities for application to alkali activated materials. 6th Symposium on Doctoral Studies in Civil Engineering, Faculty of Civil Engineering, University of Zagreb, Croatia. 7-8 September 2020. https://doi.org/10.5592/CO/PhDSym.2020.09

Jhatial, A.A., Goh, W.I., Sohu, S., Mangi, S.A. \& Mastoi, A.K. 2020b. Preliminary Investigation of Thermal Behavior of Lightweight Foamed Concrete Incorporating Palm Oil Fuel Ash and Eggshell Powder. Periodica Polytechnica Civil Engineering, pp. 1-13. https://doi.org/10.3311/PPci.16498

Jhatial, A.A., Goh, W.I., Mohamad, N., Rind, T.A., \& Sandhu, A.R. 2020c. Development of Thermal Insulating Lightweight Foamed Concrete Reinforced with Polypropylene Fibres. Arabian Journal for Science and Engineering, 45(5): 4067-4076. https://doi.org/10.1007/s13369-020-04382-0

Jhatial, A.A., Goh, W.I., Sohu, S. \& Mohamad, N. 2020d. Thermo-Mechanical Properties of Various Densities of Foamed Concrete Incorporating Polypropylene Fibres. Arabian Journal for Science and Engineering, 45(10): 8171-8186. https://doi. org/10.1007/s13369-020-04657-6

Jhatial, A.A., Goh, W.I., Mohamad, N., Mo, K.H. \& Sohu, S. 2020e. Incorporation of Palm Oil Fuel Ash and Eggshell Powder as Supplementary Cementitious Materials in Sustainable Foamed Concrete. Tehnički vjesnik, 27(5), pp. 1394-1402. https:// doi.org/10.17559/TV-20190326112511

Jhatial, A. A., Goh, W. I., Mo, K. H., Sohu, S., \& Bhatti, I. A. 2019a. Green and sustainable concrete-the potential utilization of rice husk ash and egg shells. Civil Engineering Journal, 5(1), 74-81. https://doi.org/10.28991/cej-2019-03091226

Jhatial, A.A., Sohu, S., Memon, M.J., Bhatti, N.U.K., \& Memon, D. 2019b. Eggshell powder as partial cement replacement and its effect on the workability and compressive strength of concrete. International Journal of Advanced and Applied Sciences, 6(9): 71-75.

Jhatial, A.A., Goh, W.I., Mohamad, N., Sohu, S., \& Lakhiar, M.T. 2018. Utilization of Palm Oil Fuel Ash and Eggshell Powder as Partial Cement Replacement-A Review. Civil Engineering Journal, 4(8): 1977-1984. https://doi.org/10.21833/ ijaas.2019.09.011

Jhatial, A.A., Inn, G.W., Mohamad, N., Johnson Alengaram, U., Mo, K.H., \& Abdullah, R. 2017. Influence of polypropylene fibres on the tensile strength and thermal properties of various densities of foamed concrete. IOP Conf. Ser.: Mater. Sci. Eng., 271(1): 012058. https://doi.org/10.1088/1757-899X/271/1/012058

Kamaruddin, S., Goh, W.I., Jhatial, A.A. and Lakhiar, M.T. 2018. Chemical and Fresh State Properties of Foamed Concrete Incorporating Palm Oil Fuel Ash and Eggshell Ash as Cement Replacement. International Journal of Engineering \& Technology, 2018, 7(4.30), pp. 350-354. http://dx.doi.org/10.14419/ijet.v7i4.30.22307

Lim, S.K., Tan, C.S., Lim, O.Y., Lee, Y.L. 2013. Fresh and hardened properties of lightweight foamed concrete with palm oil fuel ash as filler. Construction and Building Materials, 46: 39-47. https://doi.org/10.1016/j.conbuildmat.2013.04.015

Liu, M.Y.J., Alengaram, U.J., Jumaat, M.Z., Mo, K.H. 2014. Evaluation of thermal conductivity, mechanical and transport properties of lightweight aggregate foamed geopolymer concrete. Energy and Buildings, 72: 238-245. https://doi. org/10.1016/j.enbuild.2013.12.029

Mo, K.H., Bong, C.S., Alengaram, U.J., Jumaat, M.Z., Yap, S.P. 2017. Thermal conductivity, compressive and residual strength evaluation of polymer fibre-reinforced high volume palm oil fuel ash blended mortar. Construction and Building Materials, 130: 113-121. https://doi.org/10.1016/j.conbuildmat.2016.11.005 
Munir, A., Abdullah, Huzaim, Sofyan, Irfandi, Safwan 2015. Utilization of palm oil fuel ash (POFA) in producing lightweight foamed concrete for non-structural building material. Procedia Engineering, 125: 739-746. https://doi.org/10.1016/j. proeng.2015.11.119

Özyavuz, M., Bilgili, B.C., Elkıran, G. 2015. Temperature distribution and environmental impact of Tekirdag Ataturk Forest Nature Park. International Journal of Global Warming, 8(1): 102-113. https://doi.org/10.1504/ijgw.2015.071581

Raji, S.A., Samuel, A.T. 2015. Egg Shell as a Fine Aggregate in Concrete for Sustainable Construction. International Journal of Scientific \& Technology Research, 4(09): 8-13.

Tangchirapat, W., Jaturapitakkul, C. 2010. Strength, drying shrinkage, and water permeability of concrete incorporating ground palm oil fuel ash. Cement and Concrete Composites, 32(10): 767-774. https://doi.org/10.1016/j.cemconcomp.2010.08.008

Tangchirapat, W., Saeting, T., Jaturapitakkul, C., Kiattikomol, K., Siripanichgorn, A. 2007. Use of waste ash from palm oil industry in concrete. Waste Management, 27(1): 81-88. https://doi.org/10.1016/j.wasman.2005.12.014

Tay, J.H. 1990. Ash from oil-palm waste as a concrete material. Journal of Materials in Civil Engineering, 2(2): 94-105. https://doi. org/10.1061/(asce)0899-1561(1990)2:2(94)

Tonnayopas, D., Nilrat, F., Putto, K., Tantiwitayawanich, J. 2016. Effect of oil palm fiber fuel ash on compressive strength of hardening concrete. Proceedings of the 4th Thailand Materials Science and Technology Conference, Pathumthani, Thailand March 31-April 1, 2016: 1-3.

Ujin, F., Ali, K.S., Harith, Z.Y.H. 2017. The effect of eggshells ash on the compressive strength of concrete. Key Engineering Materials, 728: 402-407. https://doi.org/10.4028/www.scientific.net/KEM.728.402

Wei, C.B., Othman, R., Ying, C.Y., Jaya, R.P., Ing, D.S., \& Mangi, S.A. 2020. Properties of mortar with fine eggshell powder as partial cement replacement. Materials Today: Proceedings. https://doi.org/10.1016/j.matpr.2020.07.240

Yerramala, A. 2014. Properties of concrete with eggshell powder as cement replacement. The Indian Concrete Journal: 94-104.

Yusuff, A.S. 2017. Preparation and characterization of composite anthill-chicken eggshell adsorbent: Optimization study on heavy metals adsorption using response surface methodology. Journal of Environmental Science and Technology, 10(3): 120-130. https://doi.org/10.3923/jest.2017.120.130

Zahari, N.M., Rahman, I.A., Zaidi, A.M.A. 2009. Foamed concrete: potential application in thermal insulation. In Proceedings of MUCEET2009, Malaysian Technical Universities Conference on Engineering and Technology, June 20-22, 2009, MS Garden, Kuantan, Pahang, Malaysia, 2009: 47-52.

Zeyad, A.M., Johari, M.A.M., Tayeh, B.A., Yusuf, M.O. 2017. Pozzolanic reactivity of ultrafine palm oil fuel ash waste on strength and durability performances of high strength concrete. Journal of Cleaner Production, 144: 511-522. https://doi. org/10.1016/j.jclepro.2016.12.121

Zhang, J., Liu, G., Chen, B., Song, D., Qi, J., Liu, X. 2014. Analysis of CO2 emission for the cement manufacturing with alternative raw materials: a LCA based framework. Energy Procedia. 61: 2541-2545. https://doi.org/10.1016/j.egypro.2014.12.041 